Institute of $\mathbf{F}_{\text {ood and }} \mathbf{A}_{\text {gricultural }} \mathbf{S}_{\text {ciences }}$

\title{
A Spiny Orb Weaver Spider, Gasteracantha cancriformis (Linnaeus) (Arachnida: Araneae: Araneidae) ${ }^{1}$
}

G. B. Edwards ${ }^{2}$

\section{Introduction}

One of the more colorful spiders in Florida is a spiny orb weaver, Gasteracantha cancriformis (Linnaeus) 1767. Although not as large as some of the other common orb weavers (e.g., Argiope, Levi 1968; Neoscona, Edwards 1984), the combination of color, shape, and web characteristics make $G$. cancriformis one of the most conspicuous of spiders. The colloquial name for this spider in parts of Florida is "crab spider", although it is not related to any of the families of spiders commonly called crab spiders, e.g., Thomisidoe. This species belongs to a pantropical genus which contains many species in the Old World. With the possible exception of the West Indian G. tetracantha (L.) (which may be only a geographic race), G. cancriformis is the only species of its genus to occur in the New World, ranging from the southern United States to northern Argentina (Levi 1978). The bite of this common species is not known to cause serious effects to humans.

\section{Systematics}

Because of the variations in color and shape of the abdominal "spines" throughout its range, $G$. cancriformis has been described by numerous early scientists under a plethora of names (Levi 1978). Although Kaston (1978) continued the use of the name G. elipsoides (Walckenaer) 1841, resurrected by Chamberlin and Ivie (1944), Levi (1978) examined this species and found it to be a synonym of G. cancriformis.

\section{Identification}

This species can be easily distinguished from all other spiders in Florida. Females may be 5 to nearly 9 $\mathrm{mm}$ in length, but 10 to $13 \mathrm{~mm}$ wide. They have six pointed abdominal projections frequently referred to as "spines." The carapace, legs, and venter are black, with some white spots on the underside of the abdomen. The dorsum of the abdomen is, typically for Florida specimens, white with black spots and red spines. Specimens from other areas may have the abdominal dorsum yellow instead of white, may have black spines instead of red, or may be almost entirely

\footnotetext{
1. This document is EENY-167 (originally published as DPI Entomology Circular 308), one of the Featured Creatures series of the Entomology and Nematology Department, Cooperative Extension Service, Institute of Food and Agricultural Sciences, University of Florida. Published: October 2000. This document is also available on Featured Creatures Website at http://creatures.ifas.ufl.edu. Please visit the EDIS Website at http://edis.ifas.ufl.edu. Additional information on these organisms, including many color photographs, is available at the Entomology and Nematology Department website at http://entnemdept.ifas.ufl.edu/.

2. G. B. Edwards, Florida Department of Agriculture and Consumer Services, Division of Plant Industry, Gainesville, FL.
}

The Institute of Food and Agricultural Sciences (IFAS) is an Equal Employment Opportunity - Affirmative Action Employer authorized to provide research, educational information and other services only to individuals and institutions that function without regard to race, creed, color, religion, age, disability, sex, sexual orientation, marital status, national origin, political opinions or affiliations. For information on obtaining other extension publications, contact your county Cooperative Extension Service office. Florida Cooperative Extension Service / Institute of Food and Agricultural Sciences / University of Florida / Larry R. Arrington, Interim Dean 
black dorsally and ventrally. Males are much smaller than females, 2 to $3 \mathrm{~mm}$ long, and slightly longer than wide. Color is similar to the female, except the abdomen is gray with white spots. The large abdominal spines are lacking, although there are four or five posterior small humps (Levi 1978; Muma 1971).

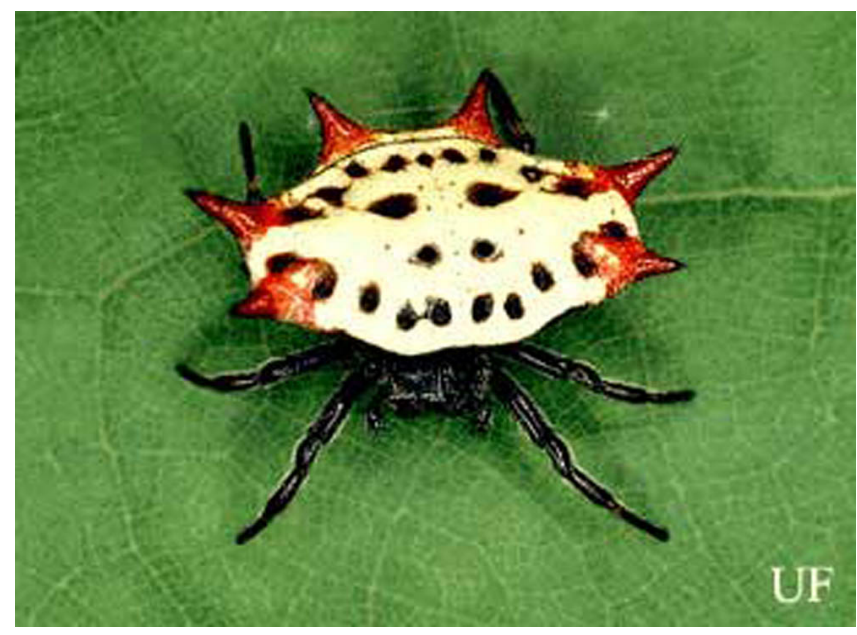

Figure 1. Female Gasteracantha cancriformis (Linnaeus), a spiny orb weaver. Credits: University of Florida

\section{Biology}

Muma (1971) discussed the life cycle and web construction of G. cancriformis in Florida. Although males have been found in every month except December and January (Levi 1978), they are most common in October and November. Females, which are found as adults throughout the year, are most common from October through January.

Mixed-mesophytic woodlands and citrus groves are where they are most frequently found. Males hang by single threads from the females' webs prior to mating, described by Muma (1971).

Ovate egg sacs, 20 to $25 \mathrm{~mm}$ long by 10 to $15 \mathrm{~mm}$ wide, are deposited on the undersides of leaves adjacent to the female's web from October through January. The egg mass consists of 101 to 256 eggs, with a mean of 169 (based on 15 egg masses). After the eggs are laid on a white silken sheet, they are first covered with a loose, tangled mass of fine white or yellowish silk, then several strands of dark green silk are laid along the longitudinal axis of the egg mass, followed by a net-like canopy of coarse green and yellow threads. Eggs are frequently attacked by specialized predators, primarily Phalacrotophora epeirae (Brues) (Diptera: Phoridae), and occasionally Arachnophago ferruginea Gahan (Hymenoptera: Eupelmidae) (Muma and Stone 1971). Eggs take 11 to 13 days to hatch, then spend two to three days in a pink and white deutova stage before molting to the first instar.

After another five to seven days, the spiderlings acquire dark coloration. Spiderlings dispersed within a week later in disturbed laboratory colonies, but remained in the eggsacs an additional two to five weeks in the field. Spiderlings make tiny, inconspicious orb webs or hang from single strands. In the late summer and early fall, significant increases occur in both body and web size. The larger webs have 10 to 30 radii. The central disk where the spider rests is separated from the sticky (viscid) spirals by an open area 4 to $8 \mathrm{~cm}$ wide. There may be as many as 30 loops of the viscid spiral, spaced at 2 to $4 \mathrm{~mm}$ intervals. The catching area of the web may be 30 to $60 \mathrm{~cm}$ in diameter. Conspicuous tufts of silk occur on the web, primarily on the foundation lines. The function of these tufts is unknown, but one hypothesis suggests that the tufts make the webs more conspicuous to birds (Eisner and Nowicki 1983), preventing the birds from flying into and destroying the webs. The webs may be less than 1 to more than $6 \mathrm{~m}$ above ground. The spiders prey on whiteflies, flies, moths, and beetles that are caught in the webs.

\section{Survey and Detection}

Citrus workers frequently encounter this species, and it may occur on trees and shrubs around houses and nurseries. Specimens may be easily collected in small vials, and are best preserved, as are all spiders, in 70 to $80 \%$ ethyl or isopropyl alcohol.

\section{Selected References}

Chamberlin, R.V., and W. Ivie. 1944. Spiders of the Georgia region of North America. Bull. Univ. Utah 35: 1-267.

Edwards, G.B. 1984. Large Florida orb weavers of the genus Neoscona (Araneae: Araneidae). Florida Dept. Agric., Div. Plant Ind., Entomol. Circ. 266: 1-2. 
Eisner, T., and S. Nowicki. 1983. Spider web protection through visual advertisement: Role of the stabilimentum. Science 219: 185-187.

Kaston, B.J. 1978. How to Know the Spiders. 3rd ed. Wm. C. Brown Co., Dubuque, Iowa. 272 pp.

Levi, H.W. 1968. The spider genera Gea and Argiope in America (Araneae: Araneidae). Bull. Mus. Comp. Zool. 136: 319-352.

Levi, H.W. 1978. The American orb-weaver genera Colphepeira, Microtheno and Gasteracantha North of Mexico. Bull. Mus. Comp. Zool. 148: 417-442.

Muma, M.H. 1971. Biological and behavioral notes on Gasteracantha cancriformis (Arachnida: Araneidae). Florida Entomol. 54: 345-351.

Muma, M.H., and K.J. Stone. 1971. Predation of Gasteracantha cancriformis (Arachnida: Araneidae) eggs in Florida citrus groves by Phalacrotophora epeirae (Insecta: Phoridae) and Arachnophaga ferruginea (Insecta: Eupelmidae). Florida Entomol. 54: 305-310. 